\title{
Výživa u australopitéků
}

\author{
Tomáš Janoušek \\ Ústav antropologie Př́rodovědecké fakulty Masarykovy univerzity, Vinařská 499/5, 60300 Brno
}

Do redakce doručeno 11. května 2015; k publikaci přijato 9. března 2016

\section{NOURISHMENT AMONG AUSTRALOPITHECINES}

ABSTRACT Methods for reconstructing diet of taxonomical tribe hominini are based on the fossil record, which provides ecological context and can be compared with recent organisms and model situations. Each method highlights a bit of knowledge about the properties of the diet, which was located in a specific environment and utilized in a specific way and so about the properties of the bones, which were adapted for obtaining a specific diet. Method limitations for old and fragmentary specimens lead to complicated interpretations and often brings only general conclusions, nevertheless provides valuable information that gradually with advancing technologies reveals the history of our ancestors and the shaping of recent people.

KEY WORDS Nourishment; hominini; australopithecus; evolution; adaptation; paleoanthropology

ABSTRAKT Metody zabývající se rekonstrukcí výživy předků člověka se opírají o fosilní záznam, nabízející ekologické souvislosti. Tento materiál lze srovnávat s recentními organismy a modelovými situacemi. Každá z metod osvětluje část spektra poznání jak vlastností stravy, která se nacházela $\mathrm{v}$ konkrétním prostředí a byla určitým způsobem využívána, tak vlastností skeletu, jenž je adaptován na získávání specifické stravy. Mnohá omezení při aplikování metod na velmi staré a fragmentární vzorky znesnadňují interpretaci a vedou k mnohdy obecným závěrům, ale přesto přináśí cenná data, která s postupně se zlepšujícími technologickými možnostmi rozkrývají historii našich dávných předků a formování dnešních lidí.

KLÍČOVÁ SLOVA Výživa; hominini; australopithecus; evoluce; adaptace; paleoantropologie

\section{ÚVOD}

Př́ijem potravy a metabolická činnost jsou jedny ze základních projevů organismu. Potřeba zajištění potravy je součástí homeostatických mechanismů, jež umožňují dostatečný přísun energie. Potravní adaptace mají zásadní vliv na biologii druhu. Ovlivňují velikost těla, způsob lokomoce, rozmnožovací a sociální chování, geografické rozšíření druhu a stejně tak rozhodují o jeho specifickém habitatu (Haas - Harrison 1977, 85-92). Mnohé $\mathrm{z}$ těchto změn, které mohly hrát důležitou úlohu v procesu hominizace a souvisí s příjmem potravy, zaznamenáváme u předků člověka (Aiello - Wheeler 1995; Ulijaszek 2002, 523-524). Při rekonstrukci výživy vyhynulých druhů je důležité brát v potaz, že nemusíme vždy vysvětlovat i vývoj potravní adaptace těchto druhů, nebot' strava, která dle našich poznatků vykazuje největší selekční tlak na druh, nemusí být nutně ta, která byla nejčastěji konzumovaná (Berthaume et al. 2010, 603). Tuto domněnku mohou dokazovat případy konzumování nouzových potravin, které mají nižší energetické hodnoty než běžně preferovaná potrava, ale zajištují přežití v určitých obdobích nedostatku běžné potravy (Marshall - Wrangham 2007). U primátů můžeme počítat i s kulturním ovlivněním potravního chování. Schopnost učení mohla být $\mathrm{v}$ proměnlivém prostředí klíčová jak pro geografickou expanzi, tak pro rozvoj kognitivních schopností (Potts 2004, 222-223). 


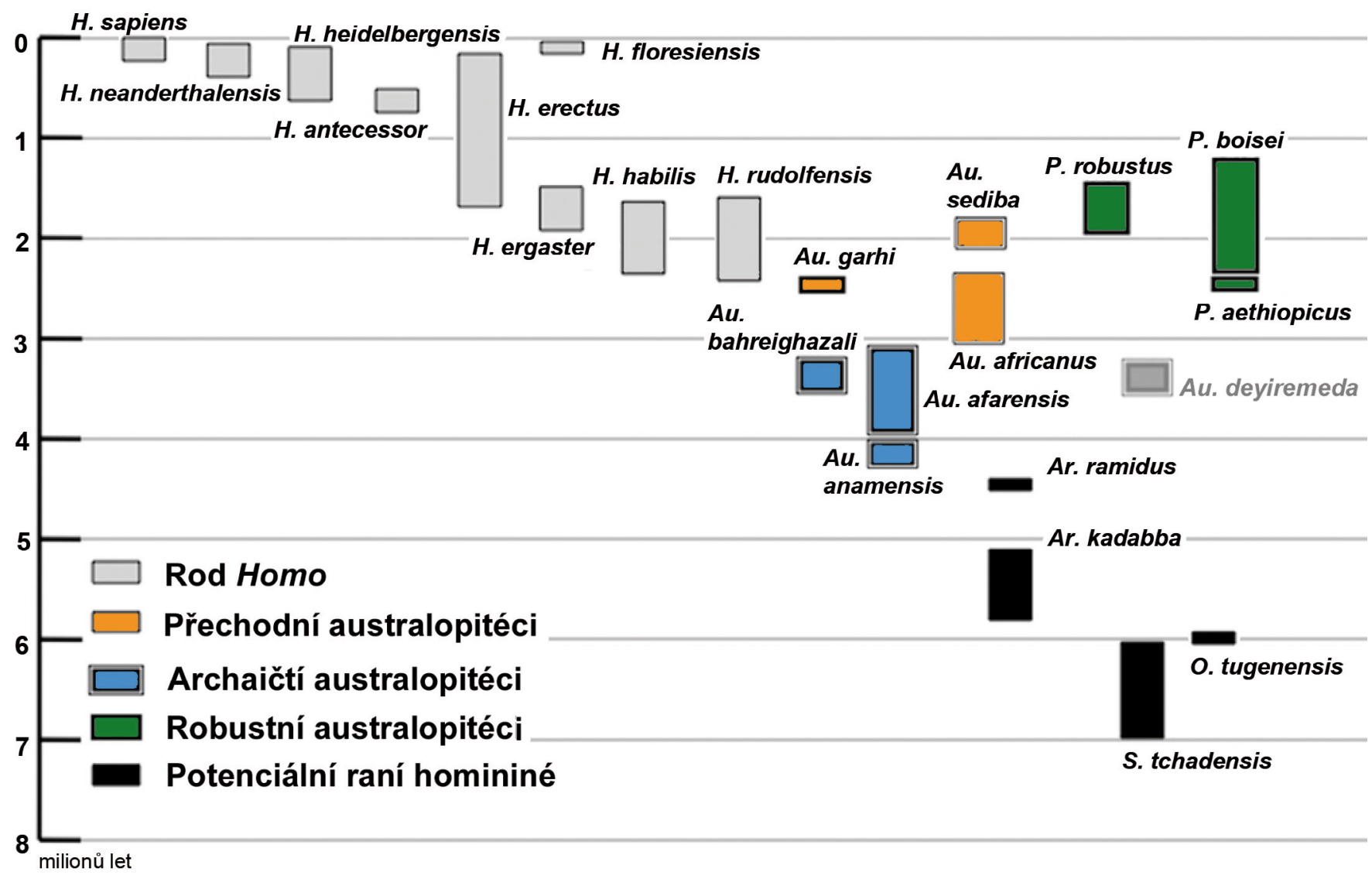

Obr. 1. Jednotlivé skupiny raných hominidů a jejich odhadovaná období výskytu (Upraveno podle: Wood 2010, 8903).

\section{AUSTRALOPITÉCI}

Mimo nejstarší možné homininy, kam patří Sahelanthropus tchadensis (cca $7 \mathrm{Ma}$ ), Orrorin tugenensis (6 Ma) a dvojice Ardipithecus ramidus (4,5-4,3 Ma) a Ardipithecus kadabba (5,8$5,2 \mathrm{Ma})$, je parafiletická skupina australopitéků větví, které je přisuzována nejstarší návaznost na rod Homo z doby odštěpení se od posledního společného předka šimpanzů a lidí. Australopitéci, rod Australopithecus, zahrnují rozdílné skupiny homininů, kteří obývali africký kontinent v období mezi 4,2-1,4 Ma. Největší rozdíly mezi australopitéky zjištujeme v oblasti kraniálního skeletu a dentice. Sdílené znaky australopitéků jsou: bipedie, průměrný objem mozkovny, odpovídající dnešním šimpanzům $\left(375-550 \mathrm{~cm}^{3}\right)$, horizontálně krátký obličej s masivní zygomaticomaxillární oblastí a s př́tomným subnasálním prognatismem, dorso-ventrálně krátké basicranium s dopředu posazeným foramen magnum. Malé řezáky, velké třenové zuby a stoličky pokryté různě silnou vrstvou skloviny. Australopitéci se dělí na archaické, přechodné nebo gracilní a robustní nebo též megadontní. Třídění homininů je zobrazeno na obrázku 1 (Senut 2007, 1520-1523; Svoboda 2014, 199-200; Wood 2010, 8907-8908).

\section{METODY PRO URČOVÁNÍ VÝŽIVY RANÝCH HOMININU゚}

Na dostupnost potravních zdrojů má zásadní vliv klima, které ovlivňuje produkci biomasy, tvořící potravní zdroje pro další organismy. Tropické deštné lesy s vysokým úhrnem srážek a vysokou průměrnou teplotou jsou schopné vyprodukovat větší množství zdrojů než na srážky chudší ekosystémy (Reed - Rector 2007, 265-267). Východní Afrika, jedna z hlavních oblastí nálezů australopitéků, byla v raném miocénu významně zalesněná. Východoafrické prostř̌edí se v období středního a pozdního miocénu začíná měnit více ve smíšené oblasti lesů a savan (Jacobs et al. 2010, 66-67). Objevují se suchomilné rostliny a trávy ( $\mathrm{s}_{4}$ fotosyntetickým aparátem), které začínají dominovat nad původním rostlinstvem ( $\mathrm{s}_{3}$ fotosyntetickým aparátem) koncem miocénu a na konci pliocénu se stávají významnou komponentou jídelníčku trávy spásajících živočichů (Feakins - de Menocal 2010, 49-50). Postupné rozšiřování savan a sezónní cykly měly za následek fragmentárnější a méně stabilní zastoupení potravy v krajině. Menší úživnost otevřených krajin pravděpodobně vyžadovala sociální a kognitivní adaptace pro efektivní získávání kvalitní potravy. 

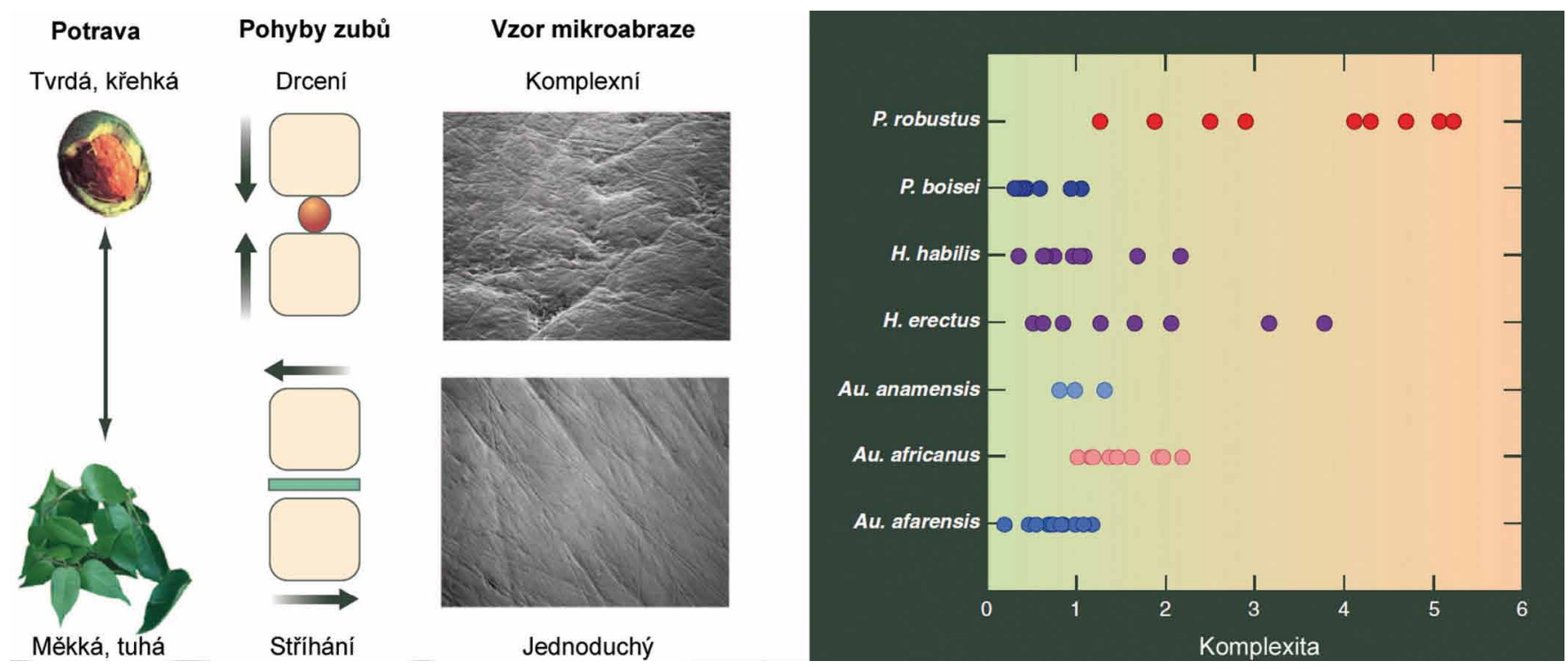

Obr. 2: Př́klad mikroabraze způsobené tvrdou/křehkou (nahoře) a měkkou/tuhou stravou, vpravo srovnání komplexity mikroabraze u některých zástupců raných hominidů (Upraveno podle: Ungar - Sponheimer 2011).

Schopnost využívat širší spektrum zdrojů u raných homininů dokazují nejen nálezy $A u$. afarensis v rozličných habitatech, ale i doklady konzumace masa v oblasti výskytu Au. garhi staré 2,5 Ma (de Heinzelin 1999, 625; Potts 2004, 224-225; Reed - Rector 2007, 276).

\section{MORFOLOGICKÉ METODY}

Morfologické hodnocení fosilních vzorků patří k nejstarším používaným metodám. Stavba lebky a zubů vypovídá mnohé o přijímané potravě a o adaptacích na určité druhy stravy, nebot' jde o oblast vstupní části zažívacího traktu. Zubní vzorec člověka a stejně tak raných homininů 2.1.2.3 je archaický, společný již pro úzkonosé opice. Řezáky a špičáky spolu s jazykem a předními končetinami mají hlavní podíl na prŕjmu potravy do trávící soustavy, přičemž třenové zuby a stoličky zajištují její rozmělňování (Fleagle 1999, 14-17). Podle struktury zubů lze odhadnout primární složku potravy. Například hmyzožraví primáti využívají ke stř́hání chitinových částí těl hmyzu výrazně vystupující ostré hrboly. Naopak frugivorní primáti mají zaoblené hrbolky na stoličkách, jejichž velký třecí povrch slouží k drcení dužiny a semen (Ungar 2007, 39-41). Nejstarší australopitéci si zachovávají poměrně velké špičáky, které se postupně zmenšují u mladších zástupců. Velikost okluzní plochy zubů se rovněž zmenšuje, výjimku tvoří robustní a někteří přechodní australopitéci (Asfaw et al. 1999, 634; Wood 2010, 8905-8906). Podobné morfologické znaky megadontních australopitéků, ale v konečném důsledku nepotvrzují jednotné potravní chování, jak dokazují rozdílné výsledky izotopických studií $A u$. boisei a $A u$. robustus, kteří sdílejí robustní kraniální skelet (Sponheimer et al. 2013, 10515; Strait et al. 2013, 341). Mikroskopická analýza zubní abraze zjištuje přímý dopad po- travy na okluzní plochy zubů. Mikroskopické změny povrchu skloviny způsobují abraziva a kyseliny přítomné v potravě, ale i externí abraziva jako hlína a písek. Stoličky pasoucích se zviŕat mají více patrnou mikroskopickou abrazi než zvířata živící se měkkými částmi rostlin a plody. Primáti pojídající tvrdou potravu vykazují větší četnost dưlků ve sklovině stoliček, zatímco primáti živící se listy mají sklovinu více rýhovanou (Obr. 2). Rostlinná strava způsobuje mikroskopickou abrazi prostřednictvím křemičitých fytolitů a $\mathrm{v}$ mnohem větším měřítku prítomností prachových a půdních částic na povrchu rostlin. $\mathrm{K}$ povrchové změně skloviny vlivem mikroabraze může dojít při přechodu na jiný druh potravy $\mathrm{v}$ rámci několika týdnů. Rozdíly jsou tedy patrné pro jednotlivá období a mezi oblastmi výskytu konkrétní potravy. Z toho vyplývá, že můžeme rozpoznat jen mikroabrazi způsobenou těšně před smrtí organismu (Teaford 2007, 106-118).

Mikrostruktura abraze okluzních ploch stoliček australopitéků v naprosté většině nenaznačuje dominanci tvrdé stravy (Obr. 3). Jedině jihoafrický megadontní $A u$. robustus má podobnou strukturu abraze s jamkováním jako primáti pojídající ořechy a tvrdá semena. Podobnou, leč mnohem méně výraznou strukturu abraze, nacházíme i u Au. africanus, dalšího jihoafrického zástupce přechodných australopitéků. Nicméně další megadontní zástupce $A u$. boisei sdílí vzor abraze s archaickými australopitéky, u kterých mikroabraze poukazuje na využívání trav, listů a ovoce a další spíše měkké potravy (Ungar et al. 2010, 3350-3352; Ungar - Sponheimer 2011).

Komparativní studie prokazují, že větší tlouštka skloviny poukazuje na př́ijem tvrdší stravy. Naopak tenká sklovina je charakteristická pro frugivorní primáty. Nicméně tento koncept může být zjednodušující, protože někteří primáti živící se primárně semeny nevykazují tlustou sklovinu. K odstranění tvrdého obalu semene (perikarpu) používají řezáky, a stoličky tak 


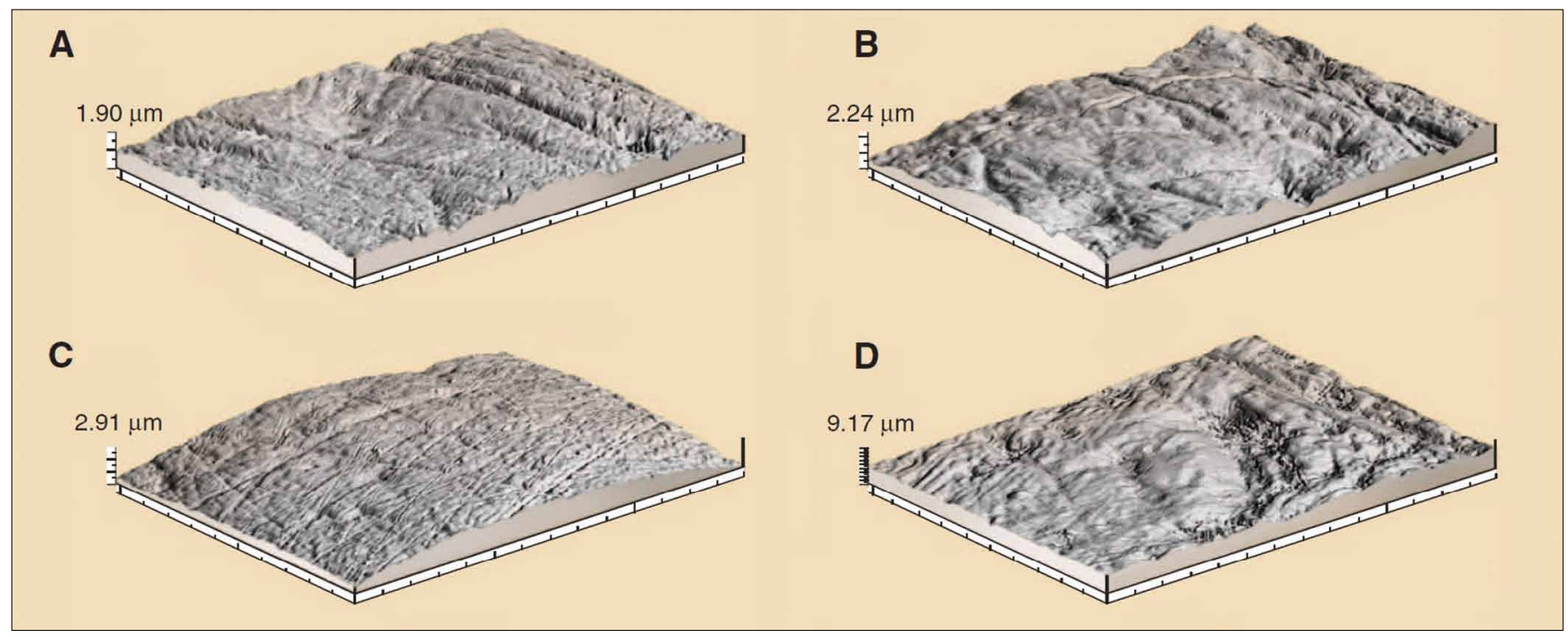

Obr. 3. Srovnání mikroabraze vzorků (A) Au. afarensis, (B) Au. africanus, (C) Au. boisei, (D) Au. robustus, snímky mají velikost 102 x $139 \mu \mathrm{m}$ (Pramen: Ungar - Sponheimer 2011, 191).
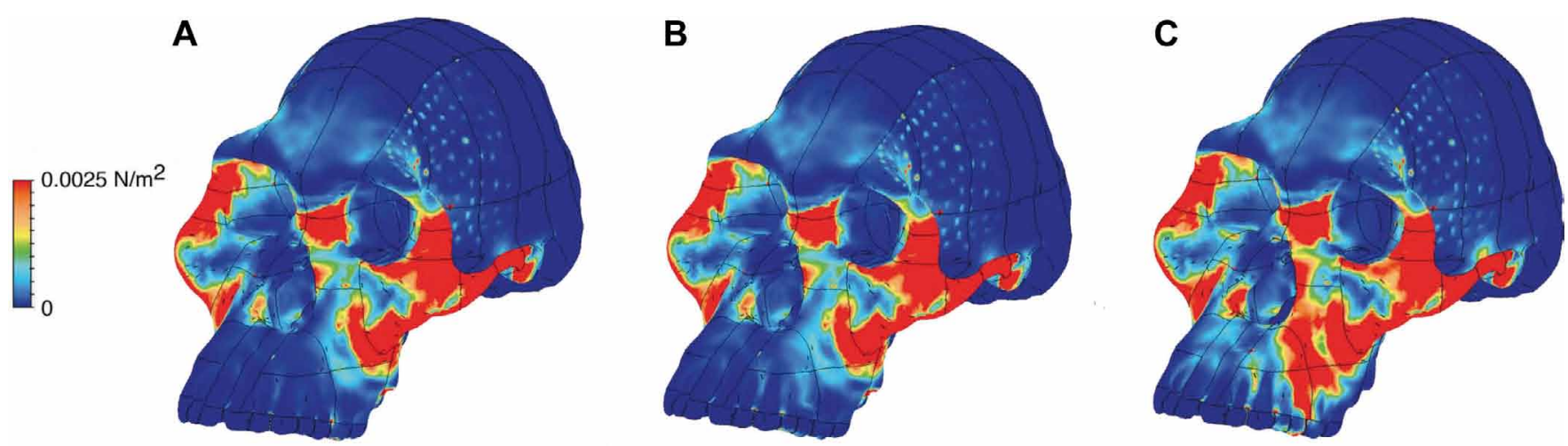

Obr. 4. Rozložení deformačních sil na lebce Au. africanus, (a) skus pouze na stoličkách, (b) skus na stoličkách a třenových zubech, (c) skus pouze na třenových zubech, teplejší barva znamená větší zatížení (Pramen: Strait et al. 2009, 2125).

zpracovávají už relativně měkkou vnitřní část. Tlustá sklovina zajištuje odolnost zubu a tím prodlužuje jeho funkčnost, což se uplatňuje především u megadontních australopitéků (Berthaume et al. 2010, 595-597). Tento znak podporuje hypotézu o využívání nouzových potravin, mechanicky náročnějších na zpracování, ale důležitých v období nedostatku běžně konzumované potravy (Wrangham et al. 2009). Sem patří prredevším podzemní zásobní orgány rostlin, které musely obsahovat mnoho externího abraziva a současně byly tuhé a významně tvrdší než listy a ovoce (Smith et al. 2015, 164).

\section{BIOMECHANICKÉ METODY}

Cennou analýzu morfologických útvarů na lebce podává deformačně-napětová metoda konečných prvků (Dumont et al. 2009). Zkoumaná struktura (model lebky) je zobrazena jako sít, v jejíž uzlových bodech jsou zjištovány specifické parametry (Obr. 4). Výsledky této metody například ukázaly, že síla skusu je obecně závislá na tělesné hmotnosti a především přinesly důležité poznatky o významu morfologických struktur lebky, které slouží jako výztuže a chrání lebku před deformacemi. Deformační síly se liší v závislosti na místě skusu. Zpracování potravy se děje především pomocí stoliček a třenových zubů. Síla skusu je sice největší na stoličkách, přesto okolní tkáně neumožňují zpracování rozměrnější potravy, a proto je vhodnější využívat stoličky $\mathrm{k}$ drcení malých částí tvrdé potravy. Třenové zuby sice mají více prostoru pro větší potravu, ale síla skusu bývá menší než u stoliček. V případě využívání nouzových potravin dochází i ke zpracování pomocí špičáků. U primátů se nejčastěji objevují zpevňující struktury právě v oblastech nad třenovými zuby a stoličkami (Strait 2009; Wroe 2010, 3583). Modelové srovnání síly skusu dokázalo, že kraniální skelet megadontního $A u$. boisei převyšuje sílu skusu $A u$. africanus i šimpanze. Jelikož však analýza abraze ukázala u $A u$. boisei příklon k měkké, prrípadně tuhé, nikoliv však tvrdé stravě, mohla by pak morfologie lebky souviset $\mathrm{s}$ repetitivní zátěží př̀ zpracovávání větších porcí potravy (Smith et al. 2015, 157-159). 

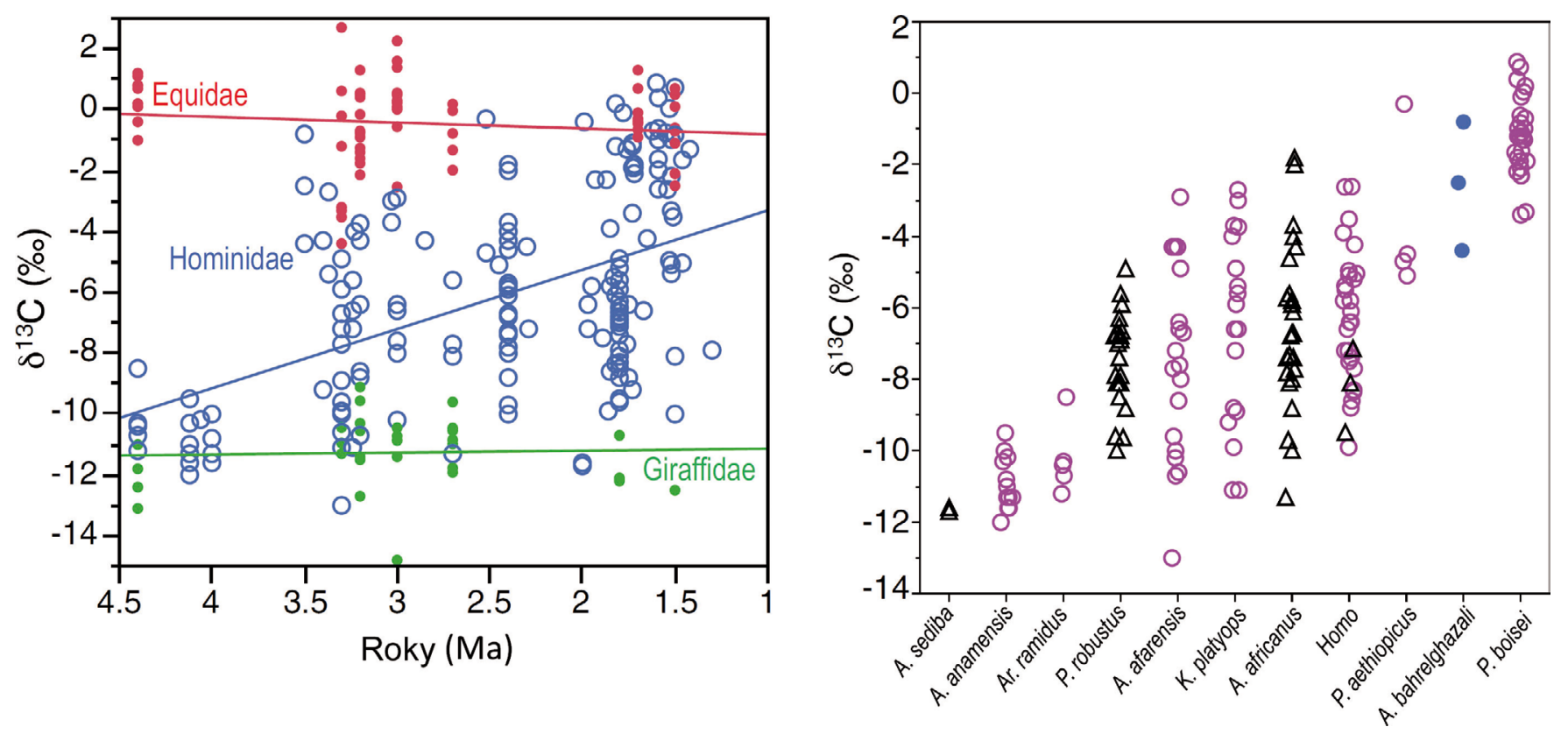

Obr. 5. Vlevo srovnání zastoupení izotopu ${ }^{13} \mathrm{C}$ u raných hominidů v porovnání s čeledí equidea (trávy spásající koně) a giraffidae (žirafovití, pojídající měkké části rostlin a plody); Vpravo srovnání zastoupení izotopu ${ }^{13} \mathrm{C}$ u vybraných raných hominidů z jižní Afriky - trojúhelník; východní Afriky - prázdný kruh; centrální Afriky - plný kruh (Pramen: Sponheimer et al. 2013).

\section{ANALÝZA STABILNÍCH IZOTOPU゚}

Geochemické složení prostředí má přímý vliv na poměrové zastoupení stabilních izotopů ve tkáních organismů. Metody analýzy stabilních izotopů nemohou přesně určit jídelníček fosilních druhů, ale mohou pomoci vymezit potravní kategorie, např́klad preferenci masa před rostlinnou potravou pomocí analýzy stabilních izotopů dusíku a poměru stopových prvků stroncia a vápníku. Stroncium je tělem přijímáno jako vápník díky podobné chemické podstatě. Je akumulováno z půdy rostlinami, jejichž konzumací býložravci část množství zabudovávají do svých těl a dále, opět s určitou ztrátou, i následní predátoři. (Reitsema 2013, 131-132; Sponheimer et al. 2005, 148). Zastoupení ${ }^{15} \mathrm{~N}$ s každým krokem vzhůru po potravním řetězci stoupá zhruba o $3 \%$. Touto metodou byla zjištěna vysoká masožravost u Homo neanderthalensis, jelikož však k ukládání izotopů dusíku dochází v organické tkáni, která podléhá velmi rychle rozkladu, je tato metoda pro vzorky raných homininů nevhodná. (Sponheimer et al. 2007, 139). Příjem proteinů $z$ vodních nebo suchozemských zdrojů lze upřesnit pomocí analýzy stabilních izotopů kyslíku. Při evaporaci vody se lehčí ${ }^{16} \mathrm{O}$ snadněji uvolňuje do atmosféry. Transpirace (fyziologický výpar vody) rostlin vede k obohacování biomasy $\mathrm{o}^{18} \mathrm{O}$. $\mathrm{K}$ tomuto procesu dochází především skrze průduchy na listech. Folivorní živočichové, kteří přijímají většinu vody formou rostlinné potravy, mají proto také větší zastoupení ${ }^{18} \mathrm{O}$ ve svých tkáních než živočichové běžně pijící z povrchových vodních zdrojů (Cerling et al. 2004). Pro zastoupení $\mathrm{C}_{4}$ rostlin $\mathrm{v}$ potravě oproti $\mathrm{C}_{3}$ rostlinám slouží analýza stabilních izotopů uhlíku, která využívá rozdílného ukládání izotopů ${ }^{13} \mathrm{C}$ a ${ }^{12} \mathrm{C}$ do rostlinné biomasy. Jejich konzumací přechází i do těl živočichů. Stromy, keře a byliny v tropických savanách využívají $\mathrm{C}_{3}$ fotosyntetické dráhy, které větší část izotopu ${ }^{13} \mathrm{C}$ vylučují. Naproti tomu suchomilné tropické trávy $\mathrm{C}_{4}$ kumulují izotopy ${ }^{13} \mathrm{C}$ ve větší míře (Clementz 2012, 371). Jednoznačnost interpretací ztěžuje kolísání zastoupení ${ }^{13} \mathrm{C}$ jak napříč různými rostlinnými druhy patřícími do obou fotosyntetických skupin a i mezi jednotlivými částmi těchto rostlin (např. vyšší zastoupení ${ }^{13} \mathrm{C}$ v plodech $\mathrm{C}_{3}$ rostlin oproti jejich listům), tak vlivy prostředí: srážkový úhrn a celoroční vodní režim spojený se sezonními cykly, půdní složení a rozdílný prístup světla $\mathrm{v}$ hustém porostu. Rozdíl zastoupení ${ }^{13} \mathrm{C}$ od standardizovaného vzorku je u typické $\mathrm{C}_{3}$ dominantní stravy $-27 \%$ a u $\mathrm{C}_{4}$ rostlinné stravy predstavuje $-12,5 \%$. Ve studii Codron et al. (2005), prováděné na vzorcích rostlin $\mathrm{z}$ jihoafrické savany, se však s přihlédnutím k výše uvedeným jevům způsobujícím rozdílné ukládání ${ }^{13} \mathrm{C}$ vyskytují odchylky od průměrných hodnot pro $\mathrm{C}_{3}$ rostliny jen o $2 \%$ a pro $\mathrm{C}_{4}$ rostliny pouze $1 \%$. Vyšší rozdíly lze zaznamenat například $\mathrm{v}$ tropickém lese $\mathrm{s}$ vysokým ročním úhrnem srážek a větší hustotou vegetace, kde je patrný pokles ${ }^{13} \mathrm{C} \mathrm{u} \mathrm{C}_{3}$ rostlin, naopak vyšší ukládání oproti průměrným hodnotám můžeme sledovat v aridních biomech. Samotný fakt, že většina konzumentů se snaží maximalizovat př́jem živin variabilní stravou $\mathrm{z}$ různých zdrojů, problematizuje snahu specifikovat rostlinnou složku pomocí izotopických analýz.

Studie hodnotící zastoupení stroncia u vzorků $A u$. africanus překvapivě nepřináší doklad o všežravosti, spíše řadí vzorky na úroveň pasoucích se zvírat, tedy konzumentů trav. Vyšší hodnoty pro $A u$. robustus mohou znamenat vyšší začlenění 

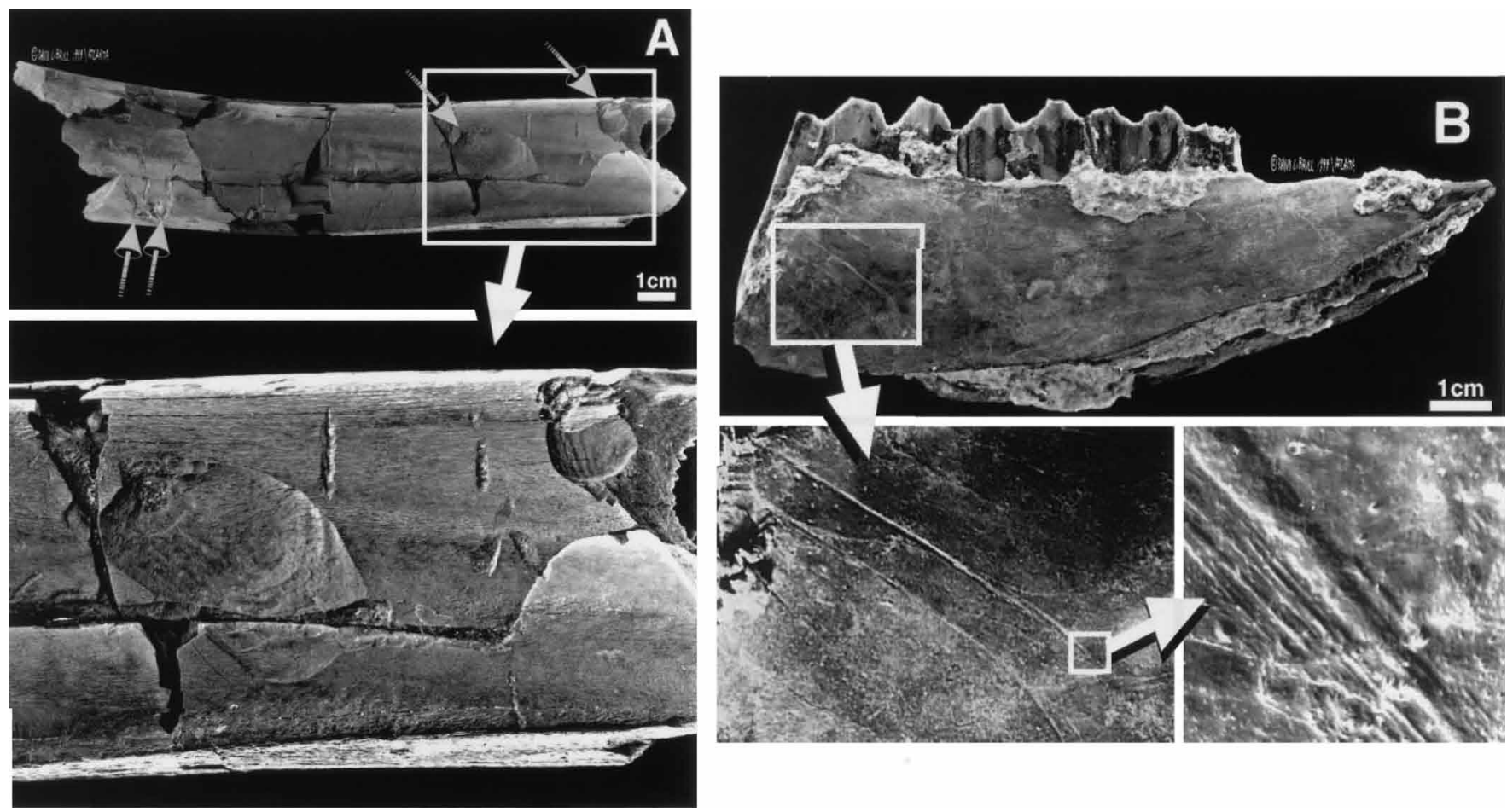

Obr. 6. Stopy řezných linií a otloukání kostí z oblasti Hata v Etiopii, (A) tibia zástupce čeledi Bovidae, BOU-VP-11/14, šedé šipky naznačují směr úderu; (B) dolní čelist buvolce, BOU-VP-12/11 (Pramen: de Heinzelin et al. 1999, 628).

živočišné stravy v jídelníčku, ale i vyšší zastoupení na stroncium bohatých podzemních orgánů rostlin (Sponheimer et al. 2005, 152-153). Způsob získávání vody, doložený analýzou izotopů kyslíku u Au. afarensis, je podobný druhům spásajícím trávu a pijícím povrchovou vodu, nikoliv druhům získávajícím vodu převážně z rostlin a ovoce (Wynn et al. 2013, 10495-10500). Vyšší zastoupení izotopu ${ }^{18} \mathrm{O}$ je doložené u $A u$. africanus a další nárůst u vzorků $A u$. robustus ze stejné oblasti zřejmě zachycuje přeměnu v aridní prostředí nebo fyziologické změny termoregulace (Sponheimer et al. 2007, 134-139). Hodnoty pro zastoupení ${ }^{13} \mathrm{C}$ ze vzorků, zobrazených na obrázku 5 , vypovídají o větší konzumaci $\mathrm{C}_{3}$ rostlin u archaických australopitéků $s$ pozdějším větším začleňováním $\mathrm{C}_{4}$ rostlin a často odrážejí vegetační zastoupení rostlin na území výskytu daných australopitéků (Cerling et al. 2013, 10501-10502; MacLatchy et al. 2010, 489-501; Sponheimer et al. 2013). Nejmarkantnější zastoupení $\mathrm{C}_{4}$ rostlin je u megadontních australopitéků s výjimkou $A$ u. robustus a u Au. bahrelghazali z Čadu (Lee-Thorp et al. 2012, 20369-20371). Naopak hodnoty zastoupení izotopư ${ }^{13} \mathrm{C}$ pro dva dostupné vzorky Au. sediba jsou velmi nízké a odpovídají naprosto převládající stravě tvořené $\mathrm{C}_{3}$ rostlinami, což není u raných homininů obvyklé, zvlášt pro období 2 Ma a mladší (Henry et al. 2012).

\section{ZOOARCHEOLOGICKÁ ANALÝZA}

Zooarcheologické nálezy poskytují jedinečné doklady o vstupu předků člověka do gildy masožravců. Podle stop na kon- krétních kostech (dokládajících bourání, stahování a porcování zvířecích těl) mưžeme určit jaká zvířata raní hominini využívali jako zdroj potravy. Zářezy na kostech od artefaktů (Obr. 6) nebo zubů nám poskytují informace o způsobu jakým byl kadaver zpracován a o ekologické interakci s ostatními masožravci. Doklady o konzumaci masa můžeme datovat do období cca 2,5 Ma v souvislosti s prvními záznamy užívání předmětů $\mathrm{v}$ rámci oldowanské kultury (Blumenschine a Pobiner 2007, 167-180; de Heinzelin et al. 1999, 625-628).

\section{ANALÝZA EKOLOGICKÝCH VZTAHŮ SE SYMBIOTICKÝMI A PARAZITICKÝMI ORGANISMY}

Mikroorganismy sídlící ve střevech a zodpovídající za specifické štěpení určitých látek poskytují značné možnosti k rozšíření potravinového spektra. Analýza fylogenetických vztahů parazitů a symbiotických bakterií s jejich hostiteli dokázala ekologické propojení určitých druhů s předky člověka. Jakákoliv změna stravy spojená se změnou střevní mikroflóry významně ovlivňuje hostitele a jeho biologickou zdatnost. Studie na africké populaci lovecko-sběračského kmene Hadzapů $\mathrm{v}$ porovnání s italskou populací prokázala rozdílné zastoupení střevních bakterií. Šlo především o bakterie zodpovědné za degradaci vysoce fibrózních rostlinných částí, tedy takové složky potravy, která je specifická pro lovecko-sběračské populace v období sucha (Schnorr et al. 2014). Dalším př́ikladem mohou být fylogenetické studie tasemnic, rod Taenia, 
jež prokázaly vazbu na lidské předky okolo 2,5-1 Ma v souvislosti $\mathrm{s}$ přechodem $\mathrm{k}$ fakultativní masožravosti a přenosem parazitů z kočkovitých šelem $\mathrm{v}$ důsledku konzumace mršin, které s těmito šelmami sdíleli. Další významný přechod tohoto parazita byl zaznamenán $\mathrm{v}$ době před 10 tisíci lety zejména v souvislosti s domestikací skotu (Hoberg 2006, 26).

\section{REKONSTRUKCE VÝŽIVY}

Primáti jsou obecně popisování jako všežravci, nicméně jejich potravní spektrum tvoří primárně rostlinná strava, která u orangutanů a goril tvoří až $99 \%$ jejich energetických přímů. Šimpanzi, kteří využívají více živočišné stravy, mají i přesto dominantní zastoupení rostlinných zdrojů ve svém jídelníčku, které tvoří 87-98\% získávané energie (Milton 2003, 3886). Nejčastěji vyhledávanou rostlinnou stravou recentních hominoidů je čerstvé ovoce. Dá se předpokládat, že totéž platilo i pro australopitéky, $\mathrm{v}$ př́padech kdy bylo dostupné (Taylor $2006,387)$. Dostupnost ovoce v savaně či v mozaikovém habitatu lesů a otevřených krajin je výrazně menší než v tropickém deštném lese. Divoce rostoucí rostliny a jejich podzemní zásobní orgány jsou sice bohaté na sacharidy, ale často se nachází ve značné hloubce pod povrchem a jsou obalené velmi tvrdou slupkou (Schoeninger 2007, 156-158). V období nedostatku jiných zdrojů měly tyto části $\mathrm{C}_{4}$ rostlin tvořit podle některých badatelů významný potravní doplněk. Výtěžek $\mathrm{z}$ těchto potravin, které mohou být energeticky bohaté, je značně snižován energetickými nároky na jejich zpracování. Potřeba využívat hojně tento zdroj, mohla vyústit ve zlepšení nástrojového chování homininů (Marshall - Wrangham 2007, 1220-1227; Potts, 2004, 224-225). Pravděpodobná přítomnost vodních zdrojů v oblastech výskytu homininů a pokusy o rekonstrukci těchto lokalit (Copeland 2007; Sponheimer et al. 2007, 139-140) předpovídají výskyt $C_{4}$ vodní vegetace: vodní traviny (Cyperaceae) a vodní makrofyta (Nymphaeaceae), jejichž zásobní orgány tvoří většinu celkového objemu rostliny a jsou mnohem lépe stravitelné než zásobní orgány rostlin ze sušších oblastí (Wrangham et al. 2009, 631-632).

Mezi živočišnou stravu, kterou konzumuji vyšši primáti, patři predevším bezobratlí živočichové. Dále hmyz s málo vyvinutým exoskeletem, který je snadněji zpracovatelný a v poměru $\mathrm{k}$ hmotnosti má větší energetickou hodnotu. Již zmiňovaní Hadzapové získávají včelí med, který zároveň obsahuje včelí larvy. Tato kombinace přináší vysoké zastoupení proteinů, tuků i sacharidů a je výhodná i díky rychlému výtěžku. Šimpanzi si ke sběru termitů pomáhají rozličnými předměty, čímž zvyšují energetický příjem na jednotku času (McGrew 2014; Schoeninger 2007, 156). Maso může být považováno za alternativu nouzových potravin, jde totiž o vhodný doplněk proteinů, na které je většina rostlinné stravy chudá. Nadměrný př́jem proteinů však zatěžuje organismus (Cordain et al. 2000, 689). Tato metabolická zátěž může způsobovat, že lovci Hadza $v$ prrípadě vydařené lovecké sezony ztrácí více tělesné hmotnosti než v lovecky méně úspěšném období (Hawkes et al. 2010, 259-260). Naleziště kostěných kumulací Hata a Olduvai svými doklady o využívání masa, spadají do oblasti výskytu Au. garhi a Au. boisei. Nelze však jednoznačně potvrdit, že kosterní kumulace byly vytvořeny jejich zásluhou, a nikoliv sympatricky se vyskytujícími zástupci rodu Homo. (Blumenschine - Pobiner 2007, 177; de Heinzelin et al. 1999, 627). Je pravděpodobné, že úspěšné linie homininů si zachovaly dostatečný př́ijem kvalitní potravy, at' už šlo o nové zdroje potravin, jejichž horší mechanickou zpracovatelnost mohli úspěšně obcházet vhodným používáním předmětů a sociálním uspořádáním, které jim přineslo energetické úspory při zajištování potravy (Potts 2004). Bohužel další fyziologické adaptace, přinášející energetické úspory $\mathrm{v}$ daných podmínkách, je těžké interpretovat $\mathrm{z}$ hlediska charakteru vzorků.

\section{ZÁVĚR}

Výčet probraných metod dokumentuje postup rozkrývání potravního chování u australopitéků, pliocénních a pleistocénních předchůdců člověka. Samostatně nám metody přinášejí hrubou představu o potravě, kterou australopitéci konzumovali nebo nám nastiňují určité trendy ve změnách výběru potravy. Úroveň nejhrubších odhadů nám přinášejí morfologické metody zkoumající jednotlivé prvky skeletu, na nichž lze dokumentovat odlišný vývoj megadontních australopitéků od ostatních zástupců. Robustní struktury lebky u nich nasvědčují konzumaci tvrdé stravy. Naproti tomu analýzy mikroabraze ukázaly, že z megadontních australopitéků využíval významněji tvrdou stravu pouze $A u$. robustus, naopak $A u$. boisei vykazuje znaky požívání měkčí, prrípadně tuhé stravy, pravděpodobně ve větším množství. Analýza mikroabraze však podává doklady jen o zpracované potravě v posledním úseku života, nebot tato informace se do značné míry neustále přepisuje (Strait et al. 2013). Tvrdší stravu v suchých sezónách mohla využívat většina australopitéků v podobě podzemních zásobních orgánů rostlin (Marshall - Wrangham 2007). Biomechanické metody dokázaly, že robustní kraniální skelet australopitéků napomáhal jak při repetitivním žvýkacím pohybu dolní čelisti, tak při vyvinutí dostatečné síly pro zpracovávání tvrdé potravy, což mohla umožňovat i silnější sklovina (Wroe et al. 2010). Moderní analýzy stabilních izotopů se s využitím izotopů uhlíku pokouší zpřesnit potravní spektrum v rámci rostlinných zdrojů na $\mathrm{C}_{4}$ rostliny (traviny a jejich zásobní orgány), které dominují u pozdějších zástupců australopitéků a na $\mathrm{C}_{3}$ rostliny (stromy a byliny a jejich plody), které jsou více zastoupeny $\mathrm{u}$ archaičtějších zástupců. Závěry $\mathrm{z}$ těchto analýz znesnadňují různé vlastnosti prostředí, v kterém se rostliny nalézají a celková izotopická hodnota vzorku, pod kterou se skrývá větší množství různé vegetace (Codron et al. 2005; Sponheimer et al. 2013). Analýza zastoupení poměru stroncia a vápníku může naznačovat vyšší zastoupení živočišné stravy u megadontního $A u$. robustus (Sponheimer et al. 2005). Masožravost je pak doložitelná především díky zooarcheologické analýze kostí nesoucích stopy se zásahy po kamenných artefaktech (Blumenschine - Pobiner 2007) a dále díky fylogenetickým vztahům s parazity vázanými na šel- 
my a následně na předky člověka (Hoberg 2006). Konkrétnější představy nám jednoznačně dává syntéza jednotlivých metod a přibývající počty studií a vzorků, se kterými je možné pracovat. Rekonstrukce výživy je ale i přes využití těchto metod velmi obecná. Pro další zpřesnění pomáhají analogie a rekonstrukce prostř̌edí, čímž zlepšujeme naše představy o možných potravních zdrojích, jejich dostupnosti a využívání.

\section{PODĚKOVÁNÍ}

Na tomto místě chci poděkovat Mgr. Sandře Sázelové, Ph.D., která mi cennými radami trpělivě pomáhala při studiu výživy předků člověka a její komentáře velkou měrou pomohly $\mathrm{k}$ tvorbě tohoto článku.

Tento článek vznikl za podpory specifického vysokoškolského výzkumu č. MUNI/A/1170/2015, kterou poskytlo MŠMT.

\section{LITERATURA}

Aiello, L. C. - Wheeler, P. (1995): The Expensive-Tissue Hypothesis: The Brain and the Digestive System in Human and Primate Evolution. $\mathrm{Cu}$ rrent Anthropology, 36(2), 199-221.

Asfaw, B. - White, T. - Lovejoy, O. - Latimer, B. - Simpson, S. - Suwa, G (1999): Australopithecus garhi: A new species of early hominid from Ethiopia. Science, 284, 629-635.

Berthaume, M. - Grosse, I. R. - Patel, N. D. - Strait, D. S. - Wood, S. - Richmond, B. G. (2010): The effect of early Hominin occlusal morphology on fracturing of hard food items. The Anatomical Record, 293(4), 594-606.

Blumenschine, R. J. - Pobiner, B. L. (2007): Ecology of Oldowan Hominin Carnivory. In: Ungar, ed., Evolution of the Human Diet: The Known, the Unknown, and the Unknowable. New York: Oxford University Press, 167-190.

Cerling, T. E. - Hart, J. A. - Hart, T. B. (2004): Stable isotope ecology in the Ituri Forest. Oecologia, 138, 5-12.

Cerling, T. E. - Manthi, F. K. - Mbua, E. N. - Leakey, L. N. - Leakey, M. G. - Leakey, R. E. - Brown, F. H. - Grine, F. E. - Hart, J. A. - Kaleme, P. Roche, H. - Uno, K. T. - Wood, B. A. (2013): Stable isotope-based diet reconstructions of Turkana Basin hominins. Proceedings of the National Academy of Sciences, 110(26), 10501-10506.

Clementz, M. T. (2012): New insight from old bones: stable isotope analysis of fossil mammals. Journal of Mammalogy, 93(2), 368-380.

Codron, J. - Codron, D. - Lee-Thorp, J. A. - Sponheimer, M. - Bond, W J. - de Ruiter, D. - Grand, R. (2005): Taxonomic, anatomical, and spatio-temporal variations in the stable carbon and nitrogen isotopic compositions of plants from an African savanna. Journal of Archaeological Science, 32, 1757-1772.

Copeland, S. R. (2007): Vegetation and plant food reconstruction of lowermost Bed II, Olduvai Gorge, using modern analogs. Journal of Human Evolution, 53, 146-175.

Cordain, L. - Miller, J. B. - Eaton, S. B. - Mann, N. - Holt, S. H. A. - Speth, J. D. (2000): Plant-animal subsistence ratios and macronutrient energy estimations in worldwide hunter-gatherer diets. The American Journal of Clinical Nutrition, 71, 682-692.

de Heinzelin, J. - Clark, J. D. - White, T. - Hart, W. - Renne, P. - Woldegabriel, G. - Beyene, Y. - Vrba, E. (1999): Environment and Behavior of 2,5-Million-Year-Old Bouri Hominids. Science, 284, 625-629.

Dumont, E. R. - Grosse, I. R. - Slater, G. J. (2009): Requirements for comparing the performance of finite element models of biological structures. Journal of Theoretical Biology, 256, 96-103.

Feakins, S. J. - de Menocal, P. B. (2010): Global and African Regional Climate during the Cenozoic. In: Werdelin - Sanders, eds., Cenozoic Mammals of Africa. Berkeley: University of California Press, 45-55.
Fleagle, J. G. (1999): Primate Adaptation and Evolution. San Diego: Academic Press.

Haas, J. D. - Harrison, G. G. (1977): Nutritional anthropology and biological adaptation. Annual Review of Anthropology, 6, 69-101.

Hawkes, K. - O'Connell, J. F. - Coxworth, J. E. (2010): Family Provisioning Is Not the Only Reason Men Hunt. Current Anthropology, 51(2), 259-264.

Henry, A. G. - Ungar, P. S. - Passey, B. H. - Sponheimer, M. - Rossouw, L. Bamford, M. - Sandberg, P. - de Ruiter, D. J. - Berger, L. (2012): The diet of Australopithecus sediba. Nature, 487, 90-93.

Hoberg, E. P. (2006): Phylogeny of Taenia: Species definitions and origins of human parasites. Parasitology International, 55, 23-30.

Jacobs, B. F. - Pan, A. D. - Scotese, C. R. (2010): A Review of the Cenozoic Vegetation History of Africa. In: Werdelin - Sanders, eds., Cenozoic Mammals of Africa. Berkeley: University of California Press, 57-72.

Lee-Thorp, J. - Likius, A. - Mackaye, H. T. - Vignaud, P. - Sponheimer, M. - Brunet, M. (2012): Isotopic evidence for an early shift to $\mathrm{C}_{4}$ resources by Pliocene hominins in Chad. Proceedings of the National Academy of Sciences, 109(50), 20369-20372.

MacLatchy, L. M. - Desilva, J. - Sanders, W. J. - Wood, B. (2010): Hominini. In: Werdelin - Sanders, eds., Cenozoic Mammals of Africa. Berkeley: University of California Press, 471-545.

Marshall, A. J. - Wrangham, R. W. (2007): Evolutionary consequences of fallback foods. International Journal of Primatology, 28(6), 1219-1235.

McGrew, W. C. (2014): The 'other faunivory' revisited: Insectivory in human and non-human primates and the evolution of human diet. Journal of Human Evolution, 71, 4-11.

Milton, K. (2003): The Critical Role Played by Animal Source Foods in Human (Homo) Evolution. The Journal of Nutrition, 133(11), 3886-3892.

Potts, R. (2004): Paleoenviromental Basis of Cognitive Evolution in Great Apes. American Journal of Primatology, 62, 209-228.

Reed, K. E. - Rector, A. L. (2007): African Pliocene Paleoecology: Hominin Habitats, Resources, and Diets. In: Ungar, ed., Evolution of the Human Diet: The Known, the Unknown, and the Unknowable. New York: Oxford University Press, 262-288.

Reitsema, L. J. (2013): Beyond Diet Reconstruction: Stable Isotope Applications to Human Physiology, Health, and Nutrition. American Journal of Human Biology, 49, 131-148.

Schnorr, S. L. - Candela, M. - Rampelli, S. - Centanni, M. - Consolandi, C. - Basaglia, G. - Turroni, S. - Biagi, E. - Peano, C. - Severgnini, M. Fiori, J. - Gotti, R. - De Bellis, G. - Luiselli, D. - Brigidi, P. - Mabulla, A. - Marlowe, F. - Henry, A. G. - Crittenden, A. N. (2014): Gut microbiome of the Hadza hunter-gatherers. Nature Communications, 5, 1-12.

Schoeninger, M. J. (2007): Reconstructing Early Hominin Diets: Evaluating Tooth Chemistry and Macronutrient Composition. In: Ungar, ed., Evolution of the Human Diet: The Known, the Unknown, and the Unknowable. New York: Oxford University Press, 150-164.

Senut, B. (2007): The earliest putative hominids. In: Hardt - Henke - Tattersall, eds., Handbook of Paleoanthropology. Berlin: Springer-Verlag, 1519-1538.

Smith, A. L. - Benazzi, S. - Ledogar, J. A. - Tamvada, K. - Smith, L. C. P. Weber, G. W. - Spencer, M. A. - Lucas, P. W. - Michael, S. - Shekaban, A. - Al-Fadhalah, K. - Almusallam, A. S. - Dechow, P. C. - Grosse, I. R. - Ross, C. F. - Madden, R. H. - Richmond, B. G. - Wright, B. W. - Wang, Q. - Byron, C. - Slice, D. E. - Wood, S. - Dzialo, C. - Berthaume, M. A. - van Casteren, A. - Strait, D. S. (2015): The Feeding Biomechanics and Dietary Ecology of Paranthropus boisei. The Anatomical Record, 298, $145-167$.

Sponheiemer, M. - de Ruiter, D. - Lee-Thorp, J. - Späth, A. (2005): Sr/Ca and early hominin diets revisited: new data from modern and fossil tooth enamel. Journal of Human Evolution, 48, 147-156.

Sponheimer, M. - Lee-Thorp, J. - De Ruiter, D. (2007): Icarus, Isotopes, and Australopith Diets. In: Ungar, ed., Evolution of the Human Diet: The Known, the Unknown, and the Unknowable. New York: Oxford University Press, 132-149.

Sponheimer, M. - Alemseged, Z. - Cerling, T. E. - Grine, F. E. - Kimbel, W. H. - Leakey, M. G. - Lee-Thorp, J. A. - Kyalo Manthi, F. - Reed, K. E. - Wood, B. A. - Wynn, J. G. (2013): Isotopic evidence of early hominin diets. Proceedings of the National Academy of Sciences, 110(26), 10513-10518. 
Strait, D. S. - Weber, G. W. - Neubauer, S. - Chalk, J. - Richmond, B. G. Lucas, P. W. - Spencer, M. A. - Schrein, C. - Dechow, P. C. - Ross, C. F. - Grosse, I. R. - Wright, B. W. - Constantino, P. - Wood, B. A. - Lawn, B. - Hylander, W. L. - Wang, Q. - Byron, C. - Slice, D. E. - Smith, A. L. (2009): The feeding biomechanics and dietary ecology of Australopithecus africanus. Proceedings of the National Academy of Sciences, 106(7), 2124-2129.

Strait, D. S. - Constantino, P. - Lucas, P. W. - Richmond, B. G. - Spencer, M. A. - Dechow, P. C. - Ross, C. F. - Grosse, I. R. - Wright, B. W. - Wood, B. A. - Weber, G. W. - Wang, Q. - Byron, C. - Slice, D. E. - Chalk, J. - Smith, A. L. - Smith, L. C. - Wood, S. - Berthaume, M. - Benazzi, S. - Dzialo, C. - Tamvada, K. - Ledogar, J. A. (2013): Viewpoints: Diet and Dietary Adaptations in Early Hominins: The Hard Food Perspective. American Journal of Physical Anthropology, 151, 339-355.

Svoboda, J. A. (2014): Předkové: Evoluce člověka. Praha: Academia.

Taylor, A. B. (2006): Feeding behavior, diet, and the functional consequences of jaw form in orangutans, with implications for the evolution of Pongo. Journal of Human Evolution, 50(4), 377-393.

Teaford, M. F. (2007): What Do We Know and Not Know about Dental Microwear and Diet? In: Ungar, ed., Evolution of the Human Diet: The Known, the Unknown, and the Unknowable. New York: Oxford University Press, 106-131.

Ulijaszek, S. J. (2002): Human eating behaviour in an evolutionary ecological context. The Proceedings of the Nutrition Society, 61(4), 517-526.

Ungar, P. S. (2007): Dental Functional Morphology. In: Ungar, ed., Evolution of the Human Diet: The Known, the Unknown, and the Unknowable. New York: Oxford University Press, 39-55.

Ungar, P. S. - Scott, R. S. - Grine, F. E. - Teaford, M. F. (2010): Molar microwear textures and the diet sof Australopithecus anamensis and Australopithecus afarensis. Philosophical Transactions of the Royal Society, 365, 3345-3354.
Ungar, P. S. - Sponheimer, M. (2011): The Diet sof Early Hominins. Science, $334,190-193$

Wood, B. (2010): Reconstructing human evolution: Achievements, challenges, and opportunities. Proceedings of the National Academy of Sciences, 107, 8902-8909.

Wrangham, R. W. - Cheney, D. - Seyfarth, R. - Sarmiento, E. (2009): Shallow-Water Habitats as Sources of Fallback Foods for Hominins. American Journal of Physical Anthropology, 140, 630-642.

Wroe, S. - Ferrara, T. L. - McHenry, C. R. - Curnoe, D. - Chamoli, U. (2010): The craniomandibular mechanics of being human. Proceedings of the Royal Society, 277(1700), 3579-3586.

Wynn, J. G. - Sponheimer, M. - Kimbel, W. H. - Alemseged, Z. - Reed, K. - Bedaso, Z. K. - Wilson, J. N. (2013): Diet of Australopithecus afarensis from the Pliocene Hadar Formation, Ethiopia. Proceedings of the National Academy of Sciences, 110(26), 10495-10500.

\section{AUTOR}

Janoušek, Tomáš Bc. (1988), absolvent bakalářského studia oboru Antropologie na Masarykově univerzitě v Brně. V současné době pokračuje v magisterském studiu.

Kontakt: Bc. Tomáš Janoušek, Ústav antropologie Př́rodovědecké fakulty Masarykovy univerzity, Vinařská 499/5, 60300 Brno, E-mail: 326922@mail.muni.cz 
